\title{
TENAGA KERJA INDONESIA DI JEPANG; STUDI TENTANG MOTIVASI YANG MELATARBELAKANGI SESEORANG MENJADI TRAINEE
}

\author{
Eko Sasongko Priyadi \\ Universitas Pamulang \\ email: ekoantrop@gmail.com
}

Paper Accepted: 21 Juni 2019 Paper Reviewed: 23-29 Juni 2019 Paper Edited: 01-18 Juli 2019 Paper Approved: 29 Juli 2019

\begin{abstract}
ABSTRAK
Sebagai salah satu negara maju di dunia, Jepang menjadi tujuan bagi para pencari kerja, khususnya dari negara-negara berkembang, tidak terkecuali Indonesia. Memperoleh pekerjaan, mendapatkan penghasilan yang lebih baik dan mencari pengalaman hidup di negeri orang yang berbedabahasa dan kebiasaannya menjadi motivasi yang mendorong mereka pergi dari kampung halamannya. Adanya perbedaan-perbedaan antara kehidupan di Indonesia dengan di Jepang telah membuat para orang Indonesia mencari strategi untuk dapat bertahan hidup dan terus bekerja hingga waktu yang ditetapkan dalam surat kontrak perjanjian kerja.Tulisan ini mendeskripsikan dan menguraikan motivasi pemuda Indonesia mengikuti program trainee di Jepang
\end{abstract}

Kata Kunci : Tenaga Kerja Indonesia Di Jepang; Trainee

\section{PENDAHULUAN}

Migrasi orang Indonesia ke luar negeri untuk mencari pekerjaan dan penghasilan yang layak telah terjadi sejak beberapa puluh tahun terkahir. Setelah kemerdekaan Indonesia pada tahun 1945, negara-negara di Kawasan TimurTengah menjadi tujuan utama untuk mendapatkan pekerjaan dan penghasilan. Faktor naiknya harga minyak pada dekade tahun 1970an telah menjadikan negara-negara di kawasan tersebut berlimpah devisa. Di samping itu, faktor kesamaan agama Islam yang di anut oleh mayoritas penduduk di Kawasan Timur-Tengah dan kesempatan untuk dapat menunaikan ibadah haji karena dekat dengan Kota Mekah dan Madinah yang menjadi pusat konsentrasi pelaksanaan ibadah tersebut. Mayoritas buruh migran Indonesia ini di dominasi oleh perempuan yag bekerja di sektor domestik

Pada dekade tahun 1980-1990-an terjadi pergeseran negara tujuan. Negara-negara di Kawasan Asean terutama Malaysia menjadi tujuan utama tenaga kerja Indonesia yang mengadu nasib di luar negeri. Faktor kedekatan jarak, kesamaan budaya, agama, bahas dan adanya jalan darat seperti di perbatasan Kalimantan dengan Malaysia Timur adalah beberapa alasan utama tenaga kerja Indonesia pergi ke Malaysia. Umumnya mereka bekerja di sektor domestik sebagai asisten rumah tangga dan sektor perkebunan sebagai buruh kelapa sawit. Perempuan tidak lagi mendominasi jumlah angkatan kerja, tetapi laki-laki juga menyedot konsentrasi jumlah karena kebutuhan tenaga kerja di perkebunan kelapa sawit.

Perpindahan negara tujuan juga terjadi karena meningkatnya kebutuhan tenaga kerja di sektor domestik di beberapa negara Asia Timur Jauh seperti Taiwan, dan Hong Kong. Besarnya gaji yang diterima dan tingginya nilai tukar dollar Hong Kong dan NT Taiwan terhadap rupiah adalah faktor yang mengiringi pindahnya tenaga kerja Indonesia ke Kawasan Asia Timur Jauh ini.

Sejak awal dekade 1990-an hingga saat ini beberapa negara di Kawasan Asia Timur Jauh lain juga mulai menjadi serbuan tenaga kerja Indonesia. Dua negara seperti Jepang dan Korea Selatan sangat membutuhkan tenaga kerja asing akibat rendahnya angkatan kerja di negara tersebut. Rendahnya pertumbuhan jumlah penduduk sebagai akibat dari rendahnya angka kelahiran, meningkatnya jumlah penduduk tua yang telah masuk kategori tidak produktif, telah 
berakibat pada rendahnya jumlah tenaga kerja produktif. (Hugo: 1995,2006)

Untuk memenuhi kebutuhan tenaga kerja khususnya di sektor industri dan pertanian, dua pemerintah tersebut menandatangani kerja sama dengan Kementrian Tenaga Kerja Republik Indonesia dalam pengiriman alumnni siswa sekolah menengah kejuruan untuk menjalankan program magang. Sekalipun kerja sama program pengiriman alumni siswa antara dua pemerintah dengan Indonesia ini menggunakan skema magang, pada kenyataannya mereka adalah tenaga kerja yag dibayar dengan upah murah. Di negara tersebut, peserta magang ini harus menghadapi realita kehidupan yang berbeda seperti agama, budaya, bahasa, etos kerja, suasana kerja dan cara hidup sehari-hari.

Tulisan ini akan menguraikan tentang motivasi dan strategi yang dilakukan oleh tenaga kerja Indonesia di Jepang agar mereka dapat bertahan hidup dan menyelesaikan kontrak "magangnya" selama tiga tahun di suatu lingkungan tempat tinggal dan tempat kerja yang memiliki perbedaan budaya, bahasa, kebiasaan hidup, etos kerja dan kepercayaan yang tajam dengan Indonesia dan kampung halaman mereka.

\section{Teknik Pengumpulan Data}

Tulisan ini dilatar-belakangi penelitian penulis saat menyelesaikan thesis di Jepang pada tahun 2005-2007. Menggunakan pendekatan kualitatif, pengumpulan data dilakukan dengan metode wawancara, baik wawancara mendalam dan wawancara sambil lalu. Berkumpul dan mengikuti berbagai kegiatan yang dilakukan oleh tenaga kerja Indonesia ini seperti pengajian, bermain sepak bola, bermain bowling, berkumpul di taman serta menginap di beberapa "mess" mereka merupakan teknik observasi terlibat yang dilakukan penulis dalam rangka pengumpulan data yang lebih komprehensif dan lengkap tanpa mengganggu aktifitas kerja informan. Data sekunder dari beberapa dokumen juga menjadi pendukung untuk memperkuat data primer yang diperoleh dari wawancara dan pengamatan.

\section{Lokasi Penelitian}

Penelitian ini dilakukan di beberapa Prefektur di sekitar Tokyo di mana terdapat beberapa tempat yang menjadi konsentrasi tenaga kerja Indonesia. Beberapa Prefektur tersebut adalah Gumma, Ibaraki dan Kanagawa. Di dalam Kota Tokyo sendiri juga terdapat beberapa tenaga kerja Indonesia, baik yang berstatus legal maupun illegal. Salah satu pertimbangan yang mendasari penulis memilih lokasi ini adalah jarak yang tidak terlalu jauh dari lokasi tempat tinggal penulis.

Lokasi- lokasi di mana terkonsentrasinya Tenaga Kerja Indonesia tersebut dapat di capai dengan menggunakan kereta commuter dari Kota Tokyo. Waktu tempuh yang dibutuhkan hanya 2 jam perjalanan. Keadaan ini memudahkan penulis untuk melakukan wawancara pada informan dan mengumpulkan data lainnya yang dilakukan dengan pengamatan atau mengikuti event-event yang mereka adakan.

Di beberapa lokasi ini terdapat banyak tenaga kerja Indonesia, yang dalam beberapa kondisi, bercampur dengan tenaga kerja Indonesia illegal. Mereka bekerja di pabrik, kebun-kebun dan perikanan. Sekalipun banyak tenaga kerja Indonesia illegal, fokus pada penelitian ini adalah "tenaga kerja" legal yang berangkat ke Jepang dengan menggunakan skema program magang.

\section{IMM Japan dan JIAEC sebagai Asosiasi Pengirim}

Terdapat dua asosiasi Jepang yang bekerja sama dengan lembaga atau badan di Indonesia untuk melakukan pengiriman orang Indonesia ke Japang untuk mengikuti program magang ini, yaitu IMM Japan dan JIAEC. Sekalipun ada beberapa asosiasi lain, namun yang umum penulis temui saat melakukan wawancara dengan beberapa informan, dua asosiasi inilah yang paling banyak melakukan pengiriman orang Indonesia ke Jepang.

\section{IMM Japan}

IMM Japan adalah singkatan dari Association for International Manpower Development of Medium and Small Enterprises Japan. Bila diterjemahkan dalam Bahasa Indonesia IMM-Japan dapat diartikan sebagai Asosiasi Pengembangan Tenaga Kerja International pada Perusahaan-Perusahaan Berskala Kecil dan Menengah di Jepang. Belakangan IMM-Japan lebih dikenal sebagai IM-Japan yang merupakan singkatan dari International Manpower Development Organization, Japan.

Assosiasi ini berdiri pada tahun 1991. Bekerja sama dengan Departemen Tenaga Kerja Republik Indonesia sebagai lembaga yang berwenang mengurusi ketenaga-kerjaan di Indonesia, IMM Japan mulai melakukan pengiriman pertama pemuda Indonesia ke Jepang pada akhir 1993 untuk mengikuti program pelatihan atau magang pada 
perusahaan-perusahaan berskala kecilmenengah di seluruh Jepang.

Sejak itu, IMM Japan secara rutin melakukan pengiriman pemuda-pemuda Indonesia yang ingin mengikuti program pemagangan di Jepang sambil mencari pengalaman kerja dan pengalaman hidup di luar negeri, menambah ketrampilan kerja dan praktek Bahasa Jepang secara langsung dengan berkomunikasi dengan penduduk setempat, mendapatkan upah bulanan selama berada di jepang dan pesangon untuk modal usaha saat kembali ke Indonesia.

Sebelum berangkat ke Jepang, mereka harus mengikuti beberapa tahapan test seperti tes administrasi, tes kesemaptaan tubuh, test Bahasa Jepang, tes Matematika, tes ketahanan fisik dan yang terdiri dari lari sepanjang $3 \mathrm{~km}$, push up 35 kali dan sit up 25 kali. Keseluruhan tes ini diakhiri dengan tes wawancara dan kesehatan. Setiap peserta harus mengikuti dan lulus pada setiap tahapan tes. Setiap peserta tidak dapat mengikuti tahapan tes berikutnya bila tidak lulus pada tahapan tes sebelumnya. Usia rata-rata calon peserta magang ini adalah 20 - 25 tahun dengan latar belakang pendidikan terendah adalah tamat SMA.

Bahkan, banyak pula trainee yang berhasil menamatkan jenjang D-3 dan S-1 dari universitas ternama di Indonesia. Beberapa informan pernah menyatakan bila mereka lulus dari Politeknik Negeri Jakarta yang dulu bernama Politeknik UI, Universitas Andalas, ITB, Universitas Bengkulu, Universitas Diponegoro dan Universitas Sebelas Maret.

Bila lulus seluruh tahapan tes peserta akan diberikan di karantina untuk mengikuti pelatihan dadalam rangka persiapan adalah 3-4 bulan. Dalam pelatihan, calon peserta diberikan materi tentang pelajaran Bahasa Jepang tingkat dasar, pengenalan budaya dan masyarakat Jepang, bidang kerja yang akan dimasuki, serta penjelasan tentang budaya kerja yang ada di perusahaan-perusahaan di Jepang. Program pelatihan persiapan ini dilaksanakan ala semimillter dan disiplin yang ketat agar calon peserta magang terlatih dengan kehidupan masyarakat Jepang yang terkenal amat disiplin. Selama tinggal dalam karantina di asrama inipun, kehidupan calon peserta magang di nilai, di mana penilaian ini dapat mempengaruhi keberangkatan seseorang. Bila nilai yang di dapat di pandang rendah, banyak melanggar kedisiplinan selama berada di asrama, tidak mengerjakan tugas Bahasa Jepang, datang terlambat atau bangun kesiangan, maka keberangkatan seorang calon dapat dibatalkan.
Namun, bagi calon peserta magang yang mempertoleh nilai baik, tidak banyak melanggar aturan dan bersikap disiplin, tepat waktu, mengerjakan tugas-tugas PR Bahasa Jepang, tepat waktu dan tidak sering datang terlambat di kelas maka peserta tersebut memiliki peluang besar untuk berangkat ke Jepang. Waktu keberangkatan sangat ditentukan pada kebutuhan tenaga kerja perusahaan-perusahaan kecil-menengah di Jepang. Bila perusahaan di Jepang sangat membutuhkan tenaga kerja, maka kebeangkatan calon pekerja akan diperecepat. Namun, bila perusahaan di Jepang tidak membutuhkan tenaga kerja dalam waktu cepat, maka keberangkatan calon pemagang akan di undur hingga batas waktu yang tidak dapat di pastikan.

Total waktu program pemagangan dan kerja di Jepang adalah tiga tahun. Mereka berada di Jepang selama tiga tahun. Pada tahun pertama, seorang pemagang, yang lebih dikenal dengan sebutan trainee atau kenshusei dalam Bahasa Jepang, akan mendapat upah 80.000 Yen yang setara dengan Rp. 8.000.000 pada tahun 2005-2007 dengan kurs 1 Yen sama dengan kurs Rp. 100,-.

Pada tahun kedua dan ketiga upah yang diterima menjadi lebih besar 90.000 Yen dan 100.000 Yen atau setara dengan Rp. 9.000.000 dan Rp.10.000.000,-. Beberapa perusahaan memberikan fasilitas bebas biaya listrik, air dan penginapan. Namun, beberapa perusahaan lain tidak memberikan fasikitas ini sehingga trainee harus membayar biaya listrik dan air yang digunakan. Pada saat tiba di Indonesia, seorang trainee akan mendapat bantuan modal usaha sebesar 600.000 Yen atau setara dengan Rp. $60.000 .000,-$.

Uang ini akan diterima bila seorang trainee telah berhasil menyelesaikan program ini hingga tiga tahun dan kembali ke Indonesia. Bila seorang trainee tidak dapat menyelesaikan program hingga tiga tahun, atau lari menjadi seorang illegal atau undocumented worker di Jepang maka uang ini tidak akan diberikan. Sebenarnya, uang ini adalah tabungan para trainee yang disisihkan dari total upah per bulan yang semestinya diterima namun tidak diketahui oleh mereka. Seorang pekerja fresh graduate, akan mendapatkan upah sebesar 180.000 Yen per bulan yang merupakan standar upah minimum di Jepang pada saat itu.

Secara umum mereka melaksanakan program pemagangan pada perusahaanperusahaan yang bergerak di bidang industri seperti logam, beton, kayu, las, pertanian dan lain-lain. Perusahaan-perusahaan berskala kecilmenengah ini tersebar di seluruh Jepang, dari 
Pulau Hokkaido di ujung utara hingga Pulau Kyushu dan Kepulauan Ryukyu di bagian selatan. Sebagian dari perusahaan-perusahaan itu terletak di wilayah perkotaan. Namun, sebagian yang lain terletak di wilayah pedesaan. Secara umum mereka melakukan pelatihan sejak pukul 08.00 hingga pukul 17.00 dengan istirahat pada 12.00-13.00. Ada kalanya perusahaan memberikan waktu istirahat singkat selama 15 menit pada pagi hari dan sore hari.

\section{JIAEC}

JIAEC adalah singkatan dari Japan International Association Economic Center. Assosiasi ini juga merupakan assosiasi pengirim trainee Indonesia ke Jepang namun berbeda dengan IMM-Japan di atas. JIAEC melakukan perekrutan langsung pemuda-pemuda yang tertarik mengikuti program magang dengan langsung mendatangi sekolah-sekolah menengah kejuruan yang di pandang berkualitas baik dan favorit di kota tersebut. JIAEC menawarkan programnya kepada siswa-siswa kelas III yang akan lulus sekolah beberapa bulan kemudian.

Dua sekolah menengah kejuruan yang di pandang berkualitas di mana alumni-alumninya banyak menjadi peserta magang dan penulis jadikan sumber informasi pada penelitian ini berasal dari Sekolah Menengah Pertanian di Kabupaten Sukabumi dan Sekolah Menengah Kejuruan Kelautan di Kabupaten Cirebon.

Hampir seluruh informan peserta magang yang di kirim oleh JIAEC berasal dari dua sekolah tersebut. Hanya sebagian kecil saja yang berasal dari SMK di luar dua sekolah tersebut. Berdasarkan penerlusuran informasi sekunder, dua sekolah ini telah menghasilkan lulusan yang tersebar dan telah bekerja di berbagai bidang di banyak perusahaan.Para alumni yang telah berhasil menyelesaikan program magang selama tiga tahun dan telah pulang ke Indonesia dianggap berhasil membawa nama baik sekolah.

Tidak banyak peserta magang (trainee) dari dua sekolah ini yang melarikan diri dari program dan menjadi "pekerja illegal" di Jepang. Kondisi ini berpengaruh pada meningkatnya penilaian dan kepercayaan JIAEC kepada sekolah sehingga proses perekrutan hampir selalu di lakukan setiap tahun. Pihak sekolahpun selalu memberikan pedoman agar para siswa yang lulus seleksi menjadi trainee di Jepang dapat mengikuti program magang hingga selesai tiga tahun dan kembali ke Indonesia para adik kelas pada tahun-tahun berikutnya tetap dipercaya untuk mengikuti proses perekrutan dan proses seleksi
Kaburnya seorang dari program magang yang kemudian menjadi "pekerja illegal" pada akan berpengaruh pada berkurangnya jumlah calon peserta yang dapat mengikuti proses perekrutan, atau bahkan penundaan hingga penghapusan proses perekrutan di sekolah tersebut. Oleh karena itu, alumni peserta magang berusaha keras agar mereka dapat selesai hingga akhir program, tidak pulang atau dipulangkan lebih awal oleh perusahaan atau asosiasi, juga tidak kabur.

Dalam proses perekrutannya, JIAEC juga melakukan seleksi melalui beberapa tes. Namun, proses seleksi dan tes ini tidak seketat dan seberat proses tes yang dilaksanakan oleh IMM-Japan. Bila di IMM-Japan terdapat proses seleksi (di antaranya tes fisik) yang cukup ketat, maka tes fisik di JIAEC, baik kuantitas dan kualitas tidak sebanyak dan tidak sepanjang proses seleksi dan tes di IMM-Japan. Bila program pelatihan dalam rangka persiapan dan pembekalan di IMM-Japan dilaksanakan selama 3-4 bulan, maka di JIAEC program ini hanya dilaksanakan selama satu bulan.

Pemberian materi dasar tentang Bahasa Jepangnya pun tidak sebanyak program pelatihan dan pembekalan di IMM-Japan. Seorang informan pernah menyatakan bila satu waktu dan secara tiba-tiba dia di minta segera berangkat ke Jepang karena kebutuhan tenaga yang mendesak pada satu perusahaan di Jepang. Informan hanya di beri waktu kurang dari dua pekan untuk mengurus seluruh syarat-syarat administrasi yang diperlukan seperti pasport, cek kesehatan, tanda-tangan surat kontrak, penyerahan ijazah sebagai jaminan dan lainlain. Informan harus bolak-balik dari dari tempat-tinggalnya di cirebon ke Jakarta untuk melengkapi dan menyerahkan seluruh dokumen yang disyaratkan.

Waktu pelaksanaan program di Jepang sama dengan program yang dilaksanakan oleh IMM, yakni 3 tahun. Upah yang di terima perbulannya lebih kecil dibanding trainee melalui IMM. Rata-rata mereka menerima upah 60.000 Yen perbulan atau setara dengan nilai Rp. 6.000.000,-. Saat kembali ke Indonesia mereka akan menerima uang untuk modal usaha sebesar 300.000 Yen, yang setara dengan nilai Rp. 30.000.000,-. Dokumen ijazah yang dijadikan jaminan dan di simpan oleh JIAEC selama mereka mengikuti program magang, akan diserahkan kembali ke pada informan saat mereka pulang dari Jepang.

Mayoritas trainee ini "dipekerjakan" di sektor pertanian maupun perikanan sesuai dengan latar belakang pendidikannya, dimana mereka alumni dari sekolah menengah pertanian 
dan sekolah menengah kelautan. Amat jarang ditemui alumni dari dua sekolah ini yang ditempatkan di pabrik dan sektor industri lainnya. Sektor pertanian dan perikanan ini pun tidak menggunakan alat-alat modern sebagaimana yang dibayangkan oleh para calon peserta magang sebelum berangkat ke Jepang. Kebanyakannya adalah industri-industri rumah tangga yang tidak diminati oleh tenaga kerja lokal atau industri kecil-menengah Jepang ini sangat sulit mencari tenaga kerja lokal sehingga harus mencari tenaga kerja dari luar Jepang.
Kebutuhan tenaga kerja ini sebagiannya dapat dipenuhi oleh trainee-trainee Indonesia.

\section{Trainee Indonesia di Jepang}

Berdasarkan data yang di publikasikan oleh JITCO, sebuah lembaga di Jepang yang berwenang mengelola pengiriman trainee yang dilakukan oleh berbegai asosiasi dan organisasi negara asal pengiriman trainee tahun 2001 hingga 2005. Dari jumlah total ini, sembilan puluh persen merupakan trainee yang dikirim melalui IMM-Japan.

Tabel 1:

Jumlah Trainee Indonesia di Jepang dan negara-negara lain tahun 2001-2005

\begin{tabular}{|l|l|r|r|r|r|r|}
\hline \multirow{2}{*}{ No. } & \multirow{2}{*}{ Asal Negara } & \multicolumn{6}{|c|}{ Tahun } \\
\cline { 3 - 7 } & & $\mathbf{2 0 0 1}$ & $\mathbf{2 0 0 2}$ & $\mathbf{2 0 0 3}$ & $\mathbf{2 0 0 4}$ & \multicolumn{1}{c|}{$\mathbf{2 0 0 5}$} \\
\hline 1. & China & 10.169 & 13.388 & 15.703 & 18.942 & 24.689 \\
\hline 2. & Indonesia & 3.061 & 2.219 & 2.388 & 2.772 & 2.586 \\
\hline 3. & Vietnam & 1.134 & 1.238 & 1.326 & 1.534 & 1.913 \\
\hline 4. & Filipina & 616 & 568 & 580 & 727 & 1.273 \\
\hline 5. & Thailand & 119 & 93 & 110 & 110 & 324 \\
\hline 6 & Lain-lain & 118 & 47 & 31 & 51 & 122 \\
\hline & Total & 15.217 & 18.053 & 20.138 & 24.136 & 30.907 \\
\hline
\end{tabular}

Sumber: Laporan JITCO tahun 2006 dalam Priyadi (2007)

Berdasarkan data di atas, jumlah trainee Indonesia selama lima tahun sejak tahun 2001 hingga 2005 berada di urutan ke-2 setelah China, yang merupakan pengirim trainee terbesar. Selain karena kedekatan jarak Jepang dengan China, kemiripan budaya serta persamaan tulisan huruf antara China dengan Jepang, trainee asal China juga dikenal ulet, pekerja keras dan bersedia bekerja lembur dengan jam kerja yang lebih panjang. Banyak orang China, khususnya kaum muda yang menjadikan Jepang sebagai negara tujuan untuk belajar dan bekerja. Bekerja di Jepang akan mendapatkan upah yang lebih besar dibanding bekerja di China. Lapangan pekerjaan yang tersediapun lebih banyak, khususnya pada bidang-bidang pekerjan yang sudah ditinggalkan orang Jepang terutama bidangbidang pekerjaan yang kotor, suit dan berbahaya.

Sementara itu trainee asal Indonesia juga diminati oleh perusahaan-perusahaan berskala kecil-menengah di Jepang karena, khususnya trainee yang berasal dari Jawa, tidak sering membuat masalah seperti lari dari program dan menjadi tenaga kerja dengan status illegal, berselisih dengan karyawan dan buruh Jepang lainnya. Juga jarang berselisih dengan pekerja asing atau trainee dari negara lain. Traineetrainee, khususnya asal Jawa, lebih mudah menerima kondisi pekerjaan sekalipun sulit, bekerja tepat waktu, bekerja keras dan ingin sukses. Nilai-nilai budaya Jawa seperti nrimo, sabar, pasrah, ulet, pantang menyerah, hormat kepada yang lebih tua, ingat kelaurga di Indonesia turut mendukung para trainee Indonesia bertahan di tempat baru sekalipun sangat berbeda nilai-nilai budaya dan agama

Sebagian dari mereka juga didukung oleh nilai-nilai agama, khususnya Islam yang mengajarkan mereka untuk selalu bersabar pada cobaan dan bersyukur pada nikmat yang diberikan Tuhan. Sekalipun hidup di Jepang sangat berat, namun mereka bersyukur karena bisa merasakan hidup di satu negara maju dan mendapatkan upah yang nilai nominalnya belum tentu sama apabila mereka tinggal di Indonesia. Selain itu, mereka juga melihat banyak pemuda yang melamar dan mengikuti test untuk dapat mengikuti program trainee di Jepang ini namun tidak dapat berangkat karena gagal pada salah satu test dari serangkaian test yang harus di lalui. Nilai syukur kepada Tuhan ini juga yang membuat sebagian trainee Indonesia di Jepang terus bertahan untuk mengikuti program hingga selesai dan dapat menyelesaikan berbagai masalah tanpa keluh kesah yang besar. Nilai syukur pada Tuhan ini tidak ada pada masyarkat Jepang karena sebagian besar masyarakat tidak mengenal Tuhan.

Selain data perbandingan jumlah trainee Indonesia dengan negara-negara lain pada tahun $2001-2005$, berikut adalah data tentang jumlah trainee di setiap Prefekture dan jumlah 
perusahaan yang mempekerjakan trainee Indonesia di Jepang sejak tahun 1993-2006. Prefekture adalah satu wilayah administrasi yang dapat disetarakan dengan Kabupaten di Indonesia. Prefekture-prefekture di bawah ini adalah prefekture-prefekture yang berlokasi di sekitar Kota Metropolitan Tokyo, seperti kotakota Bogor, Depok, Tangerang dan Bekasi yang berada di sekitar lokasi Ibukota Jakarta.

Tabel 2:

Jumlah Trainee Indonesia di bawah assosiasi IMM-Japan1993-2006

\begin{tabular}{|c|l|r|r|}
\hline No. & Prefekture & $\begin{array}{c}\text { Jumlah } \\
\text { Perusahaan }\end{array}$ & $\begin{array}{c}\text { Jumlah } \\
\text { Trainee }\end{array}$ \\
\hline 1. & Tokyo & 433 & 897 \\
\hline 2. & Chiba & 355 & 856 \\
\hline 3. & Saitama & 1.046 & 2.372 \\
\hline 4. & Gumma & 377 & 1.026 \\
\hline 5. & Ibaraki & 630 & 1.674 \\
\hline 6. & Tochigi & 224 & 574 \\
\hline 7. & Kanagawa & 617 & 1.323 \\
\hline
\end{tabular}

Berdasarkan data di atas terlihat bahwa jumlah perusahaan dan trainee terbanyak berada di Prefekture Saitama yang lokasinya berdampingan dengan Kota Metropolitan
Tokyo. Sedangkan jumlah perusahaan dan trainee paling sedikit berada di Prefekture Tochigi yang lokasi bersebelahan dengan Prefekture Saitama.

Tabel 3:

Jumlah Trainee Indonesia di bawah assosiasi IMM-Japan tahun 2005

\begin{tabular}{|c|c|c|c|}
\hline No. & Prefekture & $\begin{array}{c}\text { Jumlah } \\
\text { Perusahaan }\end{array}$ & $\begin{array}{l}\text { Jumlah } \\
\text { Trainee }\end{array}$ \\
\hline 1. & Tokyo & 34 & 152 \\
\hline 2. & Chiba & 24 & 81 \\
\hline 3. & Saitama & 95 & 395 \\
\hline 4. & Gumma & 55 & 272 \\
\hline 5. & Ibaraki & 40 & 181 \\
\hline 6. & Tochigi & 30 & 140 \\
\hline 7. & Kanagawa & 51 & 182 \\
\hline
\end{tabular}

Sumber: IMM-Japan tidak dipublikasikan dalam Priyadi (2007)

Mengacu pada data di atas dapat disimpulkan bahwa pada tahun 2005, Prefekture Saitama tetap menjadi Prefekture dengan jumlah perusahaan berskala kecil-menengah terbanyak menerima trainee Indonesia dengan jumlah trainee 395 orang yang merupakan jumlah trainee terbanyak dibanding prefektureprefekture lain di sekitar Tokyo. Sedangkan prefekture dengan jumlah perusahaan berskala kecil-menengah paling sedikit menerima trainee Indonesia berada di Prefekture Chiba dengan jumlah trainee kurang dari 100 orang, yakni 81 orang.

\section{Tenaga Kerja Indonesia di Jepang: "trainee" sebagai cheap labor}

Meskipun pemuda Indonesia berangkat ke Jepang menggunakan nama program pemagangan dan mengikuti program magang di beberapa perusahaan di Jepang selama tiga tahun, pada kenyataannya mereka adalah tenaga kerja yang di bayar upah murah di bawah standar gaji tenaga kerja orang Jepang. Beberapa bidang pekerjaan dan lapangan kerja yang ditawarkan dan dimasuki oleh trainee Indonesia tersebut adalah lapangan kerja yang mulai ditinggalkan dan sudah kurang diminati oleh tenaga kerja muda Jepang.

Bentuk lapangan kerja ini dikenal dengan sebutan 3 D dalam terminologi Bahasa Inggris yakni dangerous, difficult dan dirty atau $3 \mathrm{~K}$ dalam terminologi Bahasa Jepang yakni kiken, kitsui dan kitanai yang diartikan berbahaya, sulit dan kotor. Lapangan kerja ini berada di pabrikpabrik, kebun-kebun untuk bercocok tanam dan memetik hasil panen. Juga bidang perikanan seperti memisahkan ikan dari es, membersihkan kotoranya, menjemur ikan dan mengepak dalam kemasan.

Tenaga kerja muda Jepang lebih memilih bidang dan lapangan kerja yang memerlukan keahlian sesuai latar belakang pendidikan 
mereka. Tempat kerja yang diinginkan adalah tempat kerja yang bersih, memiliki udara pendingin, memakai pakaian rapi, berdasi, menggunakan jas serta bekerja di belakang meja dengan satu unit komputer atau lap top di hadapannya.

Dalam tulisan ini penulis menggunakan terminologi trainee karena dalam peraturan ke imigrasian di Jepang, perusahaan dan industri berskala kecil-menengah (small-medium scale enterprises) tidah diperbolehkan menggunakan tenaga kerja asing apabila perusahaanperusahaan tersebut tidak memiliki kantor cabang dan pabrik di negara lain. Juga, bila jumlah tenaga kerja lokal yang bekerja di satu perusahaan tersebut tidak lebih dari 50 orang. Namun, pada kenyataannya perusahaanperusahaan, sangat sulit memenuhi kebutuhan tenaga kerjanya karena lapangan kerja yang terkenal dengan istilah $3 \mathrm{~K}$ dan $3 \mathrm{D}$ ini mulai ditinggalkan angkatan muda kerja Jepang.

Untuk memenuhi kebutuhan tenaga kerja dan mensiasati peratura ketenaga-kerjaan dan imigrasi ini para pengusaha berskala kecilmenengah ini mengajukan pengiriman tenaga kerja asal luar Jepang dengan menggunakan sistem trainee. Secara sederhana trainee adalah orang yang mendapatkan program pelatihan untuk meningkatkan keahlian atau skill seseorang. Namun, dalam realitanya trainee lebih banyak berperan sebagai tenaga kerja asing yang dibayar dengan upah yang lebih rendah dibanding tenaga kerja lokal yang dikenal dengan sebutan cheap labor. Padahal, beban kerja yang dilakukan sama dengan beban kerja tenaga kerja lokal dan beban jam kerja trainee juga sama dengan beban jam kerja tenaga kerja lokal. Dalam tulisan ini, penulis lebih mendekati arti trainee dengan pemahaman cheap labor atau tenaga kerja murah.

\section{Motivasi}

Ada beberapa motivasi yang menjadi pendorong seseorang menjadi trainee di Jepang sekalipun mereka harus hidup di suatu negara dengan bahasa, budaya, etos kerja, lingkungan yang sangat berbeda dengan Indonesia. Apalagi, mereka harus berpisah dari orang tua dan keluarga yang membuat mereka harus mandiri. Artinya, mereka harus melakukan segalanya sendiri tanpa bantuan siapapun kecuali teman satu di satu penginapan. Berbagai macam pekerjaan yang belum pernah mereka lakukan sebelumnya harus dikerjakan sendiri saat berada di Jepang seperti memasak, mencuci, menyeterika dan menjemur pakaian. Pekerjaanpekerjaan yang dianggap aneh oleh masyarakat
Jepang bila pekerjaan itu tersebut dilakukan oleh anak laki-laki.

Beberapa motivasi yang melatar-belakangi seseorang menjadi trainee di Jepang diuraikan pada point-point berikut:

\section{a. Mendapatkan dan Mengumpulkan Uang}

Salah satu latar belakang yang mendominasi pemuda Indonesia menjadi trainee di Jepang adalah upah per bulan dan uang modal usaha yang ditawarkan oleh IMMJapan dan JIAEC. Nilai upah akan di terima berada di atas rata-rata penghasilan seorang karyawan di Indonesia. Dengan upah rata-rata Rp.8.000.000 - Rp. 10.000.000,- per bulan bagi trainee IMM-Japan dan Rp. 5.000.000 - Rp. 6.000 .000 bagi trainee JIAEC, seorang trainee yang berasal dari desa akan menganggap nilai upah tersebut sangat besar. Nilai upah inipun belum termasuk upah lembur yang akan ditambahkan pada upah bulanan bila trainee bekerja di luar jam kerja yang ditetapkan.

Pekerjaan akan dianggap lembur bila pekerjaan tersebut:

1) Dilakukan di atas jam 17.00. Umumnya jam kerja di perusahaanperusahaan Jepang di mulai pukul 08.00 hingga 17.00. Setelah melewati batas jam kerja tersebut, maka seorang karyawan akan mendapatkan upah lembur. Upah lembur ini juga diberikan kepada trainee Indonesia bila bekerja di luar jam kerja reguler. Upah lembur di hitung per satu jam dengan besaran nilai upah yang berbeda-beda antara satu perusahaan dengan perusahaan lainnya. Secara umum, rata-rata upah lembur di Jepang berkisar 600 yen -1.000 yen atau setara dengan Rp.60.000 - Rp. 100.000. Trainee Indonesia yang dikirim oleh asosiasi IMM Japan menerima upah lembur rata-rata 800 yen hingga 1.000per jam.

2) Dilaksanakan pada Hari Sabtu, Hari Minggu dan tanggal merah atau hari libur nasional. Secara umum, tidak banyak perusahaan yang mempekerjakan karyawannya di hari libur nasional pada kalender nasional Jepang. Seperti libur nasional musim panas pada Bulan Agustus, libur nasional musim dingin pada akhir Bulan Desember dan akhir tahun serta libur nasional golden week yang merupakan hari libur nasional selama satu minggu pada akhir April hingga awal Mei setiap tahunnya. 
Beberapa perusahaan memberikan upah lembur bila karyawannya bekerja pada waktuwaktu di atas. Banyak trainee Indonesia bekerja lembur dengan bekerja di luar jam kerja reguler karena ingin menambah penghasilan. Umumnya, trainee Indonesia bekerja lembur pada pukul 17.00-20.00 pada hari kerja setiap harinya. Beberapa trainee Indonesia yang bekerja di bidang perikanan pernah mendapatkan upah hingga 20 juta rupiah perbulan saat perusahaan tempat mereka bekerja mendapat banyak order seperti saat menjelang liburan musim panas dan saat menjelang akhir tahun karena banyaknya pesanan ikan pada waktu-waktu tersebut.

Pada masa-masa banyaknya pesanan ini, seorang trainee dapat bekerja sejak pukul 3.30 pagi hingga pukul 11-12 malam. Istirahat malam hanya dilakukan selama 4-5 jam saja karena keesokan paginya mereka harus berangkat kerja kembali. Keadaan akan semakin berat bila pekerjaan itu pada musim dingin dimana waktu malam lebih panjang di banding waktu siang dan suhu udara berkisar antara 1-5 derajat celcius.

\section{b. Belajar Hidup Mandiri}

Motivasi kedua trainee Indonesia pergi ke Jepang adalah ingin belajar hidup mandiri. Pergi ke Jepang memberikan kesempatan bagi mereka untuk belajar hidup mandiri karena mereka tinggal jauh dari orang tua dan keluarga besar. Berbagai aktifitas yang selama ini tidak pernah dilakukan sendiri saat tinggal di Indonesia seperti mencuci, menjemur dan menyetrika baju, mencuci piring, memasak nasi, membuat sayuran, belanja kebutuhan hidup ke pasar, membersihkan kamar dan halaman menjadi aktifitas yang mau tidak mau harus mereka lakukan. Kebanyakan dari mereka masih di bantu oleh orang tua saat menyelesaikan berbagai aktifitas-aktifitas di atas. Sebagian trainee menyatakan bahwa mereka ingin merasakan hidup jauh dari orang tua dan keluarga besar dimana setiap permasalahan hidup di Jepang harus bisa diselesaikan sendiri

Budaya Jepang sangat terkenal dengan kebersihannya, menyelesaikan pekerjaan dengan sempurna dan tepat waktu. Trainee Indonesia harus mampu menyelesaikan seluruh pekerjaan rumah dan membagi waktu agar pekerjaan rumah itu tidak mengganggu aktifitas kerja di perusahaan. Kondisi ini membuat para trainee harus pandai pula menjaga kondisi fisik agar tidak mudah sakit akibat beban kerja yang berat dan diluar dugaan mereka.

Berbagai pekerjaan di Jepang umumnya dilakukan sendiri. Hal ini juga berlaku bagi masyarakat Jepang. Tidak ada pembantu atau asisten rumah tangga untuk menyelesaikan satu pekerjaan rumah karena gaji yang harus dibayar sama dengan pekerjaan. Namun, kondisi ini justru membuat para trainee belajar tentang hidup mandiri. Mereka menjadi terbiasa dan tidak canggung bila pulang ke Indonesia harus bekerja mandiri

\section{c. Mencari Pengalaman Hidup Di Luar Negeri}

Mayoritas usia trainee Indonesia di Jepang berada di bawah 25 tahun. Sebagian kecil saja yang berusia antara 25 hingga 30 tahun. Pada masa-masa usia ini mereka beranggapan bahwa pengalaman hidup mereka masih minim. Oleh karena itu mereka masih memandang perlu untuk mendapatkan pengalaman hidup yang lebih luas dan bersosialisasi dengan banyak orang dari berbagai latar belakang. Salah satu cara untuk mendapatkan pengalaman hidup yang lebih luas itu adalah dengan pergi dan bekerja di luar negeri.

Hidup dan tinggal di luar negeri seperti negara Jepang menjadi satu pengalaman hidup membanggakan. Tidak pernah terbersit sebelumnya bila mereka, yang kebanyakan tinggal di daerah pedesaan di Indonesia dapat pergi merantau jauh ke luar negeri, apalagi ke suatu negera yang memiliki yang memiliki biaya hidup tinggi dan terkenal karena kemajuan teknologinya. Dalam alam pikiran mereka, pergi ke Jepang adalah suatu mimpi yang sulit terwujud karena besarnya biaya yang dibutuhkan untuk sampai ke sana. Namun di sisi lain, mereka juga dapat membanggakan diri kepada orang lain, baik keluarga, kerabat, tetangga dan teman bila mereka pada satu waktu pernah merasakan tinggal di Jepang dalam jangka waktu tiga tahun. Satu hal yang belum tentu bisa diwujudkan oleh setiap orang.

Satu pengalaman hidup yang di terima oleh trainee Indonesia adalah tentang cara kerja yang sempurna, tidak boleh melakukan kesalahan fatal dan cara kerja tepat waktu. Beberapa pemilik perusahaan sering kali marah karena tidak puas dengan hasil kerja mereka ataupun marah tanpa sebab. Pada awalnya, sebagian trainee Indonesia ini terkejut dengan teguran yang keras. Namun, seiring jalannya waktu mereka menjadi terbiasa terhadap teguran ini.

Mereka beranggapan bahwa hal tersebut merupakan watak dan karakter sang pemilik yang kerap marah tanpa sebab. Kondisi ini menjadi pengalaman hidup baru bagi trainee Indonesia sehingga mereka menjadi lebih mengenal karakter orang dan budaya kerja suatu perusahaan. Kajian William (2003) tentang 
Tenaga Kerja Wanita Indonesia di Hong Kong juga terungkap bahwa salah satu tujuan menjadi buruh migran sana adalah untuk mencari pengalaman hidup di luar negeri.

Di Jepang, mereka dapat merasakan hidup di suatu negara yang memiliki empat musim: semi, panas, gugur dan dingin, di ana pada saat musim dingin mereka bisa merasakan turunnya salju yang tidak ada di Indonesia. Mereka juga dapat melihat mekarnya bunga terkenal di sana yakni Bunga Sakura pada saat awal musim semi.. Pada event-evet tertentu mereka dapat melihat pesta kembang api yang selalu dilaksanakan setiap tahun, naik kereta api cepat shinkansen, mudahnya bepergian ke manapun, terkoneksinya sarana trasportasi antara kereta dengan kereta dan antara kereta dengan bis.

Objek wisata terkenal seperti Gunung Fuji, pusat perdagangan cinema dan elektkronik Akihabara, pusat fashion Harajuku dan Shibuya, Kota Osaka dan lainnya menjadi lokasi-lokasi favorit yang telah dikunjungi yang selama ini hanya dapat dilihat di majalah atau televisi. Hal ini dapat dilakukan hanya dengan mengikuti program trainee.

\section{d. Menambah Wawasan}

Selain beberapa motivasi yang telah disebutkan di atas, salah satu alasan trainee Indonesia pergi ke luar negeri untuk menjalani program pelatihan ini adalah untuk menambah wawasan. Mendapatkan dan mengumpulkan uang tidak selalu menjadi alasan utama mereka pergi ke luar negeri, terutama mereka yang masih berusia muda dan masih memiliki kesempatan untuk mengembangkan karir bila suatu waktu bekerja, baik menjadi pegawai negeri atau bekerja di perusahaan saat mereka kembali ke Indonesia. Mengetahui dunia luar sebanyak-banyak menjadi tujuan yang lebih penting untuk pengembangan diri mereka.

Studi William (2003) mengungkapkan pula salah satu motivasi menjadi buruh migran di Hong Kong adalah untuk "memperluas cakrawala". Di Jepang, trainee Indonesia berharap mendapat sesuatu yang baru. Bertemu dengan orang-orang Jepang yang berbeda budaya dan kebiasaan hidupnya, bertemu dengan trainee dari negara lain, teman-teman trainee dari berbagai daerah lain di Indonesia dan ingin tahu tentang teknologi maju di negara asalnya. Beberapa trainee mengakui bila mereka bisa memiliki alat-alat modern seperti seperti laptop, hand phone terbaru, digital camera, handy cam, play stasion portable, fasiltas internet setelah mereka berada di Jepang. Bila di Indonesia, sangat tidak mungkin mereka memiliki alat-alat modern tersebut karena harganya yang sangat mahal. Di Jepang, mereka dapat mengikuti dan membeli keluaran terbaru alat-alat modern tersebut karena mereka mampu membeli.

Sebagian trainee menggunakan kesempatan ini untuk meningkatkan kapasitas pengetahuan, kemampuan dan keahlian yang berkaitan dengan alat-alat teknologi yang diharapkan dapat berguna bagi mereka ingin berwirausaha saat kembali ke Indonesia. Misalkan, teknik memfoto suatu objek, teknik merekam suatu event dengan menggunakan handy cam dan menghasilkan kualitas rekaman yang bagus, mengedit foto hingga menghasilkan kualitas gambar yang berkualitas, mengupload foto dan video ke berbagai media sosial seperti youtube dan facebook. Teknik-teknik dan keahlian-keahlian ini didapatkan dengan autodidak, belajar sendiri melalui media youtube. Mereka mengakui bila di Indonesia, belum tentu mereka bisa memiliki alat-alat modern dan belajar secara autodidak untuk mengup-grade keahlian-keahlian tersebut.

\section{e. Ingin Tahu Jepang: Bahasa dan Budayanya}

Jepang adalah negara maju yang telah di kenal di Indonesia. Berbagai produk dan mereknya sangat familiar di telinga orang Indonesia. Produk-produk kendaraan bermotor seperti Honda, Yamaha, Suzuki, Kawaski, Toyota, Daihatsu, Nissan dan Mitsubishi sangat banyak digunakan oleh masyarakat Indonesia. Begitu pula dengan merek-merek produk teknologi yang lain seperti Sony, Canon, Nikon, Panasonic, Sharp adalah merek-merek yang terkenal dengan kehandalan.

Di samping produk-produk teknologi, produk-produk budaya berupa film juga dekat dengan masyarakat di Indonesia. Berbagai film seperti Dora-emon, Crayon Sin Can, Oshin, Kaptain Tsubasa dan Grup Pop AKB 48 adalah produk-produk yang juga sangat di kenal oleh masyarakat Indonesia. Populernya produkproduk film dan grup pop menjadi motivasi trainee untuk beradu nasib ke Jepang. Mereka ingin tahu tentang bahasa Jepang. Mereka juga ingin tahu tentang budaya Jepang di tempat asalnya.

Beberapa trainee memiliki kemampuan Bahasa Jepang yang sangat baik. Hal ini terjadi karena setiap hari mereka harus berkomunikasi dalam Bahasa Jepang dengan pemilik perusahaan, karyawan Jepang, tetangga atau saat mengurus dokumen-dokumen penting seperti KTP dan perpanjangan visa di kantor pemerintah agar mereka dapat terus tinggal dan 
bekerja di Jepang. Sebagian mereka mengikuti kursus Bahasa Jepang gratis yang diselenggarakan oleh volunteer-volunteer masyarakat lokal di kantor-kantor "kelurahan" dan di kantor pos. Sebagian lagi mengikuti kursus Bahasa Jepang yang selenggarakan oleh asosiasi pengirim trainee. Bahkan, tidak sedikit trainee Indonesia yang lulus ujian kemampuan Bahasa Jepang level-2 dan level-1 yang dilaksanakan dua kali setahun yang dilaksanakan di seluruh dunia. Kemampuan Bahasa Jepang yang baik ini sangat membantu mereka saat kembali ke Indonesia agar bisa masuk dan bekerja di perusahaan Jepang dengan mudah. Ada pula yang membuka lembaga kursus Bahasa Jepang, sekaligus sebagai agen pengirim trainee ke Jepang

\section{f. Membantu Orang Tua}

Terakhir, faktor yang memotivasi mereka berangkat ke Jepang adalah ingin membantu orang tua. Hampir sebagian besar trainee mengirim uang yang mereka apat setiap bulannya ke Indonesia. Pengiriman uang dilakukan tergantung pada kondisi keuangan trainee dan kebutuhan keluarga di Indonesia. Pengiriman uang dapat dilakukan satu bulan sekali. Namun ada pula yang melakukan pengiriman dua bulan atau lebih dari tiga bulan per satu kali pengiriman.

Umumnya, pengiriman uang didilakukan melaui jasa pengiriman illegal, yakni jasa pengiriman uang oleh orang Indonesia yang ada di Jepang karena biaya jasa pengiriman lebih murah dibanding melalui jasa pengiriman resmi seperti official bank atau bank post Japan. Selain itu, melalui jasa pengiriman resmi akan menghadapi berbagai macam pertanyaan dari petugas Bank tentang dari mana asal uang yang akan di kirim, apa hubungan antara pengirim dan penerima dan untuk keperluan apa pengirmanuang tersebut. Di samping itu, si pengirimpun akan di mintai data identitas pribadi. Ini berbeda dengan jasa pengiriman illegal yang tidak memerlukan identitas pribadi apapun kecuali nama dan nomor rekening tujuan serta pertanyaan lainnya.

Uang yang dikirim trainee dugunakan untuk berbagai macam keperluan seperti kebutuhan biaya hidup sehari-hari, merenovasi rumah, melunasi biaya pendidikan baik biaya pendidikan adik maupun biaya kuliah kakak si pengirim. Bahkan ada pula yangdipakai untuk membantu biaya pernikahan salah satu anggota keluarga atau melunasi hutang-hutang orang tua. Namun ada pula, pengiriman uang ini dilakukan untuk berinvestasi seperti membeli tanah atau sawah di desa, atau untuk membangun rumah.

Bagi orang Indonesia pada umumnya, juga trainee Indonesia di Jepang,

keluarga menjadi bagian yang penting dalam kehidupan mereka. Seberapan jauh mereka pergi, ingatannya akan kembali ke kampung halaman, terutama orang tua dan keluarga. Pentingnya orang tua dan keluarga (terutama bagi yang belum menikah) bagi trainee Indonesia itu diwujudkan dalam bentuk pengiriman uang saat keluarga di Indonesia membutuhkan uang untuk berbagai keperluan hidup. Apalagi, sebagian mereka juga datang dari daerah pedesaan yang sangat kental dengan nilai-nilai agama, yang sangat menekankan pentingnya berbakti pada orang tua.

\section{KESIMPULAN}

Deskripsi di atas menunjukkan bahwa motivasi yang melatarbelakangi seseorang 'mengadu nasib' menjadi buruh migran di luar negeri tidak semata-mata di latar-belakangi oleh materi atau mengumpulkan uang. Mencari pengalaman hidup baru dan menambah wawasan juga menjadi motivasi yang dominan pada trainee Indonesia di Jepang. Hal ini terjadi karena mayoritas usia mereka yang masih muda dan belum menikah menjadi salah satu faktor bahwa pengalaman hidup dan luasnya wawasan sangat diperlukan untuk pengembangan diri mereka pada masa-masa berikutnya.

Belum adanya beban tanggung-jawab sebagai kepala keluarga yang harus memenuhi kebutuhan hidup bagi keluarga karena mayoritas trainee Indonesia belum menikah, juga menjadi faktor dimana penambahah ilmu, wawasan, dan peningkatan keahlian dapat mereka lakukan. Mereka tidak hanya fokus dengan kerja dan menghasilkan uang saja, tetapi mereka juga berusaha untuk menguasai teknologi, selama mereka masih berada di Jepang, negara asal teknologi tersebut. Hal ini berbeda dengan tenaga kerja Indonesia di negara lain seperti Saudi Arabia dan Malaysia yang fokus untuk mendapat uang karena mereka memiliki keluarga di Indonesia yang harus dibiayai hidupnya setiap bulan. (Tirtosudarmo: 2005)

\section{DAFTAR PUSTAKA}

Hachiya Takashi. (2001). "Technical Intership Program: Its Reality and Issues", Japan NGO Network on Indonesia (JANNI). Tokyo: Reserach Report

Hugo, Graeme. (1995). "International Labor Migration dan the Family: Some 
Observations from Indonesia", Asian Pasific Migration Journal 4-2\&3: 273-303

Hugo, Grame. (2006). Indonesia's Labor Looks Abroad. January 06, 2006.

http://www.migrationinformation.org/profiles/di splay.cfm?id=39

Komai, Hiroshi. (2001). Foreign Migrants in Contemporary Japan. Melbourne: Trans Pasific Press

Mori, Hiromi. (1997). Immigration Policy and Foreign Workers in Japan. London: Macmillan Press LTD. Page 1-60

Okushima, Mika. (2005). Introduction to a special issue:International Trends of Indonesian migrant workers and their employment system in Japan", Intercultural Communication Studies 17: $1-47$

Priyadi, Eko Sasongko. (2007). Indonesian Workers in Japan: A Social Profile and Study of Survival Strategy. Thesis untuk memperoleh gelar master pada Departement Area Studies Sophia University, Japan: Tidak dipublikasikan
Pudjiastuti, Tri Nuke. (2005). "The dynamics of Indonesian migrant workers under national and local policies: The Oarai Case", Intercultural Communication Studies 17: 79:104

Selleck, Yoko. (2001). Migrant Labour in Japan. New York: Palgrave.

Williams, Catharina Purwani. (2003). "Eastern Indonesian Women on the Move: Domestic Work in Global Cities", Antropologi Indonesia: Indonesian Journal of Social and Cultural Anthropolgy. Th.XXVII No.72: 83-100.

Tirtosudarmo, Riwanto. (2005). "The Making of a Minahasan community in Oarai: Preliminary research on social institutios of Indonesia migrant workers in Japan", Intercultural Communication Studies 17: 105-138.

http://www.moj.jp http://www.imm.or.jp http://www.jitco.or.jp. http://www.jiaec.co.id 